\title{
PERBANDINGAN METODE DEMPSTER SHAFER DAN CERTAINTY FACTOR UNTUK DIAGNOSIS PENYAKIT TANAMAN TERONG (Studi Kasus Dusun Kejoren, Desa Gerbo, Kec. Purwodadi)
}

\author{
Mohammad Hasan Basri, Ali Mahmudi, Nurlaily Vendyansyah \\ Program Studi Teknik Informatika S1, Fakultas Teknologi Industri \\ Institut Teknologi Nasional Malang, Jalan Raya Karanglo km 2 Malang, Indonesia \\ 1618055@scholar.itn.ac.id
}

\begin{abstract}
ABSTRAK
Permasalahan yang dihadapi oleh para petani tanaman terong di Dusun Kejoren, Desa Gerbo Kecamatan Purwodadi adalah kerusakan tanaman terong yang disebabkan oleh serangan penyakit. Para petani sering mengalami kerugian pada musim panen, karena tanamanya mati terserang penyakit. Penyakit tersebut biasanya menyerang tanaman petani pada musim penghujan, sehingga tingkat kegagalan panen pada musim penghujan sangat tinggi. Kurangnya pengetahuan petani tentang penyakit dan cara menanggulangi menjadi penyebab dari tanaman terong mudah terserang penyakit.

Pada penelitian ini menggunakan metode Dempster Shafer dan Certainty Factor untuk membangun sistem pakar diagnosis penyakit tanaman terong. Data yang digunakan pada penelitian ini berupa data gejala, data penyakit, dan data solusi pengendalian yang didapatkan dari Balai Pengkajian Teknologi Pertanian Jawa Timur (BPTP), dan divalidasi oleh pakar yang ahli dalam bidang pertaniann.

Berdasarkan hasil pengujian dilakukan oleh 1 orang pakar didapatkan presentase setuju $70 \%$ dan kurang setuju 30\%. Pengujian keakuratan perhitungan pada sistem dan perhitungan perhitungan manual dan didapatkan nilai presentase rata - rata error sebesar 3,65\%. Dan metode yang lebih baik antara metode Dempster shafer dan Certainty Factor adalah metode Dempster-Shafer dengan nilai presentase hasil diagnosis yang sama dengan pakar sebesar $80 \%$.
\end{abstract}

Kata kunci : Sistem Pakar, Terong, Dempster shafer, Certainty Factor.

\section{PENDAHULUAN}

\subsection{Latar Belakang}

Permasalahan yang dihadapi oleh para petani tanaman terong di Dusun Kejoren, Desa Gerbo Kecamatan Purwodadi adalah kerusakan tanaman terong yang disebabkan oleh serangan penyakit pada tanaman terong. Kebanyakan petani mengalami kegagalan pada saat musim panen karena tanaman terongya sudah banyak yang mati terserang penyakit seperti penyakit antraknosa, layu bakteri, layu fusarium, busuk buah dan ada beberapa jenis penyakit lainnya. Kebanyakan petani tanaman terong mengalami gagal panen pada musim penghujan, karena penyakit - penyakit tersebut sering menyerang pada musim penghujan. Kurangnya pengetahuan petani tentang penyakit yang menyerang tanaman terong juga menjadi salah satu penyebabnya tanaman terong terserang penyakit.

Masalah yang di alamai oleh kelompok tani di Dusun Kejoren Desa Gerbo ini dalam bidang Teknologi Informasi dan Komunikasi dapat diselesaikan dengan teori sistem pakar. Sistem Pakar adalah sebuah sistem yang digunakan untuk memecahkan sebuah masalah menggunakan teknologi komputer dan pengetahuan manusia. Ada banyak metode yang dapat digunakan dalam penyelesaian sistem pakar. Seperti penelitian yang dilakukan oleh Handayani dan Soegiarto pada tahun 2016 dengan mengembangkan sebuah sistem pakar yang sudah ada. Sistem pakar diagnosis penyakit tanaman semangka menggunakan metode Dempster Shafer berbasis web[1]. Pada tahun 2014 dilakukan pemelitian oleh Mira orisa dan kawan - kawan yang berjudul Sistem pakar diagnosis penyakit kambing berbasis web menggunakan metode Certainty Factor. [2].

Pada penelitian ini menggunakan metode Dempster Shafer dan Certainty Factor untuk pakar diagnosis penyakit tanaman terong. Hasil dari perhitungan kedua metode akan dibandingkan. Data yang digunakan untuk sistem pakar ini adalah berupa data gejala, data penyakit dan data solusi pengendalian yang didapatkan dari seorang pakar yang ahli pertanian dari Balai Pengkajian Teknologi Pertanian Jawa Timur (BPTP), sehingga untuk validasi atau kebenarannya dapat dipertanggung jawabkan. Data penelitian yang diperoleh tersebut akan diolah menggunakan sistem pakar dan dihitung dengan menggunakan metode dempster shafer dan certainty factor. Sistem pakar yang dirancang diwujudkan kedalam sebuah aplikasi komputer berbasis web dan memanfaatkan bahasa pemrograman php dan mysql.

\subsection{Rumusan Masalah}

Rumusan masalah pada pembuatan sistem pakar diagnosis penyakit tanaman terong adalah sebagai berikut:

1. Bagaimana membandingkan metode Dempster Shafer dan Certainty Factor yang lebih efektif.? 
2. Bagaimana membangun sistem pakar di Dusun Kejoren, Desar Gerbo,Kec Purwodadi?

3. Bagaimana mengembangkan sistem pakar berdasarkan data yang diperoleh dari pakar ahli tanaman terong.?

4. Bagaimana cara membandingkan metode Dempster Shafer dan Certainty Factor pada sistem pakar penyakit tanaman terong.

5. Bagaimana mengembangkan pemerograman $p h p$ dan mysql database.?

\subsection{Tujuan}

Adapun tujuan pada pembuatan sistem pakar diagnosis penyakit tanaman terong adalah sebagai berikut:

1. Membandingakan Metode Dempster Shafer dan Certainty Factor untuk diagnosis penyakit tanaman terong, metode mana yang lebih efektif sesuai dengan hasil dari pakar.

2. Membangun sistem pakar penyakit tanaman terong yang menggunakan perbandingan metode dempster shafer dan certainty factor.

3. Menghasilkan Sistem pakar menggunakan data dari Balai Pengkajian Teknologi Jawa Timur (BPTP) dengan dibimbing pakar ahli Ir. Donald Sihombing.

4. Menghasilkan perbandingan hasil perhitungan setiap metode untuk dicari nilai terbaik untuk menentukan jenis penyakit.

5. Menghasilkan Sistem pakar diagnosis pada penyakit tanaman terong dibangun dengan menggunakan Bahasa pemrograman $p h p$ dan mysql sebagai database.

\subsection{Batasan Masalah}

Batasan masalah pada tanaman terong ungu (Solanum melongena $\mathrm{L}$ ) pembuatan sistem pakar diagnosis penyakit tanaman terong adalah sebagai berikut:

1. Data yang digunakan untuk mengembangkan sistem pakar ini merupakan data jenis penyakit, data gejala dan data pengendalian pada tanaman terong yang di dapatkan dari pakar ahli tanaman terong dari Balai Pengkajian Teknologi Pertanian Jawa Timur.

2. Teknik pengambilan keputusan dalam perancangan sistem pakar ini menggunakan nilai probabilitas dari faktor kepastian yang dimiliki pada masing - masing gejala.

3. Metode yang digunakan dalam mengembangkan sistem pakar ini adalah Dempster - Shafer dan Certainty Factor.

4. Platform yang digunakan dalam mengembangkan sistem pakar yang digunakan berbasis web.

5. Bahasa pemerograman yang digunakan untuk mengembangkan sistem pakar ini php dan database yang digunakan mysql.

6. Pada website sistem pakar hanya memunculkan hasil diagonsa dari penyakit tanaman terong ungu
(Solanum melongena L) dan informasi pengendaliannya.

7. Data yang digunakan untuk penelitian ini berjumlah 7 data penyakit dan 25 data gejala penyakit yang di dapatkan dari pakar ahli dalam bidang pertanian (tanaman terong).

\section{TINJAUAN PUSTAKA}

\subsection{Penelitian Terkait}

Penelitian yang dilakukan oleh Handayani dan Soegiarto pada tahun 2017 dengan mengembangkan sebuah sistem pakar yang sudah ada. Sistem pakar diagnosis penyakit tanaman semangka menggunakan metode Dempster - Shafer berbasis WEB. Hasil dari penelitian ini membantu petani dalam hal mendiagnosis penyakit tanaman semangka dan solusi pengendaliannya, tanpa harus menunggu petugas atau pergi ke Balai Proteksi Tanaman Pangan dan Holtikultura (BPTPH) untuk melakukan konsultasi. [1]

Penelitian beriktunya yaitu perancangan sistem pakar untuk mendiagnosis penyakit pada tanaman cabe dengan menggunakan metode Certainty Factor yang dilakukan oleh Kurniawan dan Rahmad di tahun 2012 memiliki permasalahan yang dialami oleh para petani yang berupa masalah penyakit pada tanaman cabe mereka yang membuat produksi dan penghasilan para petani menjadi menurun drastis. Sehingga dibutuhkan sebuah system untuk dapat mendiagnosis jenis penyakit dan memberikan solusi untuk pengendaliannya. Dihasilkan sebuah sistem pakar yang menggunakan metode Certainty Factor untuk diagnosis penyakit tanaman cabe dan untuk solusi pengendaliannya [3].

Maulana, dkk pada tahun 2016 mengembangkan sebuah sistem pakar dengan menggunakan metode Dempster-Shafer penyakit pada tanaman karet OPT (Organisme Penganggu Tanaman) yang sangat merugikan petani karet karena menyebabkan penurunan hasil produksi tanaman karetnya [4].

Normawardah pada tahun 2018, melakukan penelitian menggunakan Certainty Factor, menjelaskan bahwa banyaknya hambatan para petani tanaman jagung yang disebabkan oleh serangan hama dan penyakit yang mengganggu produksi tanaman jagung yang terserang hama dan penyakit. Sehingga dibuatkan sebuah sistem untuk memudahkan para petani mengetahui informasi jenis penyakit dan hama yang menyerang tanaman jagung serta memberikan solusi untuk pengendalian terhadap tanaman yang terserang penyakit. [5]

Mira orisa dan kawan - kawan pada tahun 2014 melakukan penelitian berjudul Sistem pakar diagnosis penyakit kambing berbasis web menggunakan metode Certainty Factor. Sistem pakar untuk diagnosis penyakit pada kambing agar membantu para peternak untuk mendiagnosis jenis penyakit dan mengetahui cara penanganan penyakit dengan menjawab pertanyaan - pertanyaan yang telah diajukan oleh sistem, sehingga dapat menghasilkan 
keluaran untuk setiap masukan yang diberikan oleh user (peternak) [2].

\subsection{Dasar Teori}

\subsubsection{Sistem Pakar}

Sistem pakar merupakan cabang dari Artifical intelligence (AI) yang cukup tua karena sistem ini mulai di kembangkan pada pertengahan 1960. Sistem pakar merupakan istilah yang muncul untuk memcahkan masalah, sistem pakar menggunakan pengetahuan seorang pakar yang dimasukan kedalam komputer.[6]

Sistem pakar dibentuk oleh 2 komponen utama yaitu knowledge based and inference engin. Basis pengetahuan adalah proses penyimpanan pengetahuan seorang pakar ke dalam komputer[7]

\subsubsection{Dempster Shafer}

Dempster Shafer merupakan generalisasi dari teori Bayesian probabilitas subjektif. Dimana kebutuhan probabilitas yang akan dibutuhkan untuk setiap pertanyaan dari keinginan, fungsi kepercayaan berdasarkan pada tingkat kepercayaan (percaya diri atau percaya) untuk sebuah pertanyaan dalam probabilitas untuk sebuah pertanyaan tertentu. Kerangka shafer's dapat memberikan kepercayaan mengenai proposi untuk dapat direpresentasikan sebagai interval, diliputi dengan 2 buah nilai, kepercayaan (atau dukungan), belief $\leq$ plausibility. [1]

Secara umum Teori Dempster Shafer ditulis dengan suatu interval: [Belief, Plausibility]. Belief (Bel) adalah ukuran kekuatan evidence dalam mendukung suatu himpunan proposisi. Jika bernilai 0 maka mengindikasikan bahwa tidak ada evidence, dan jika bernilai 1 menunjukkan adanya kepastian. Plausibility $(\mathrm{Pl})$ dinotasikan sebagai persamaan 1:

$$
\operatorname{Pl}(s)=1-\operatorname{Bel}(s) \quad \ldots(1)
$$

Plausibility juga bernilai 0 sampai 1. Jika kita yakin akan, maka dapat dikatakan bahwa $\operatorname{Bel}(\mathrm{s})=1$, dan $\mathrm{Pl}(\mathrm{s})=0$. Andaikan tidak ada informasi apapun untuk memilih hipotesis tersebut, maka nilai: $\mathrm{m}\{\varnothing\}=1,0$ Andaikan diketahui $\mathrm{X}$ adalah subset dari, dengan $\mathrm{m} 1$ sebagai fungsi densitasnya, dan $\mathrm{Y}$ juga merupakan subset dari dengan $\mathrm{m} 2$ sebagai fungsi densitasnya, maka kita dapat membentuk fungsi kombinasi $\mathrm{m} 1$ dan $\mathrm{m} 2$ sebagai $\mathrm{m} 3$, yaitu sebagai persamaan 2:

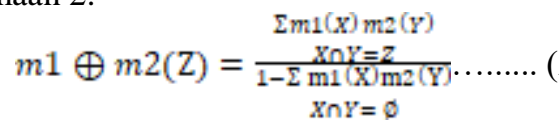

Keterangan $=$

$\mathrm{m} 1 \oplus \mathrm{m} 2(\mathrm{Z})=$ mass function dari evidence $(\mathrm{Z})$

$\mathrm{m} 1(\mathrm{X})=$ mass function dari evidence $(\mathrm{X})$

$\mathrm{m} 2(\mathrm{Y})=$ mass function dari evidence $(\mathrm{Y})$

$\mathrm{k}=$ jumlah evidential conflict.

\subsubsection{Certainty Factor}

Certainty Factor (CF) menunjukan ukuran kepastian terhadap suatu fakta atau aturan. Dalam menghadapi suatu masalah sering ditemukan jawaban yang tidak memiliki kepastian penuh. Hasil yang tidak pasti disebabkan oleh dua factor yaitu aturan yang tidak pasti dan jawaban pengguna yang tidak pasti atas suatu pertanyaan yang diajukan oleh sistem.

Dalam mengekspresikan derajat keyakinan digunakan suatu nilai yang disebut Certainy Factor (CF) untuk mengasumsikan derajat keyakinan seorang pakar terhadap suatu data. [5]

Berikut adalah formulasi dasar dari Certainy Factor dalam persamaan3:

$\mathrm{CF}[\mathrm{H} . \mathrm{E}]=\mathrm{MB}[\mathrm{H}, \mathrm{E}]-\mathrm{MD}[\mathrm{H}, \mathrm{E}] \ldots . .(3)$

Keterangan:

CF : Certainy Factor (faktor kepastian) dalam hipotesis $\mathrm{H}$ yang dipengaruhi oleh fakta $\mathrm{E}$.

MB : Measure of Belief (tingkat keyakinan), adalah ukuran kenaikan dari kepercayaan hipotesis $\mathrm{H}$ dipengaruhi oleh fakta $\mathrm{E}$.

MD : Measure of Disbelief (tingkat ketidakyakinan), adalah kenaikan dari ketidakpercayaan hipotesis $\mathrm{H}$ dipengaruhi fakta $\mathrm{E}$.

E : Evidence (peristiwa atau fakta).

$\mathrm{H}$ : Hipotesis (Dugaan).

\subsubsection{Tanaman Terong}

Tanaman terong diduga berasal dari Indonesia dan India. Tanaman ini tersebar dan dibudidayakan di banyak Negara, misalnya di daerah Karibia, Malaysia, Afrika Tengah, Afrika Timur, Afrika Barat, Amerika Selatan, dan daerah tropic. Pada umumnya tanaman ini juga dibudidayakan di daerah Eropa bagian selatan, Uni Soviet, dan Selandia Baru. Oleh karena tersebar dibanyak Negara, tidak mengherankan apabila tanaman ini memiliki nama nama khas di Negara atau di daerah tertentu, misalnya eggplant, gardenegg, aubergine, melongena, brinjal, eierplant, eirefrucht (eropa) dan masib banyak lagi sebutannya [8]

\section{METODE PENELITIAN}

\subsection{Desain Sistem}

Desain sistem pada sistem pakar diagnosis penyakit tanaman terong dapat di lihat pada Gambar 1. Gambar 1 ditunjukan interaksi antara user dengan sistem telah dibuat, yang dapat di akses menggunakan personal komputer (PC) atau Smartphone melalui web browser yang terhubung dengan koneksi internet.

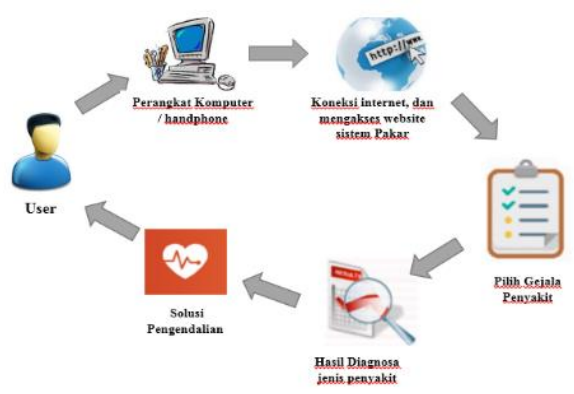

Gambar 1 Desain Sistem 


\subsection{Struktur Menu}

Pada website sistem pakar diagnosis penyakit tanaman terong ini memiliki 4 menu utama yaitu Menu Beranda, Menu Terong, Menu Kontak Kami dan Menu Login, seperti pada Gambar 2.

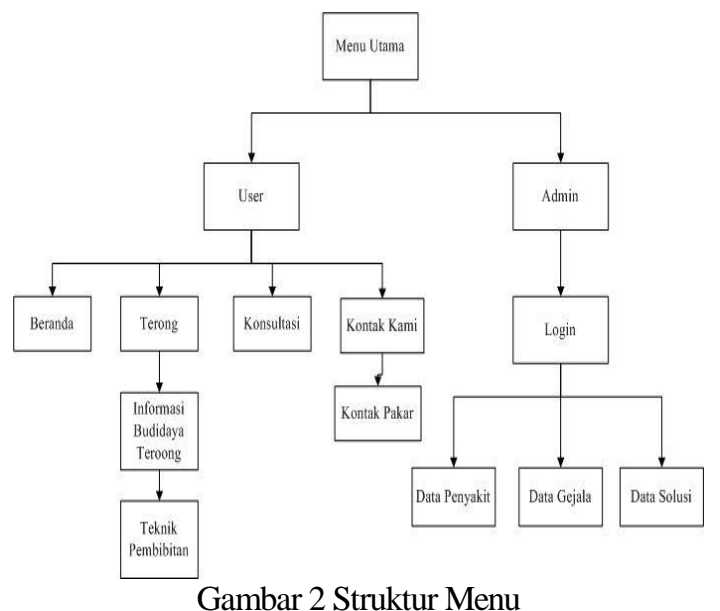

3.3 Sistem Pakar

1. Tabel Penyakit

Tabel 1 Tabel Penyakit

\begin{tabular}{|c|l|}
\hline KODE & \multicolumn{1}{|c|}{ NAMA PENYAKIT } \\
\hline P001 & ANTRAKNOSA \\
\hline P002 & BUSUK BUAH \\
\hline P003 & BUSUK LEHER AKAR/ BUSUK PANGKAL BATANG \\
\hline P004 & LAYU BAKTERI \\
\hline P005 & LAYU FUSARIUM \\
\hline P006 & BERCAK DAUN \\
\hline P007 & REBAH SEMAI \\
\hline
\end{tabular}

\section{Tabel Gejala}

Tabel 2 Tabel Gejala

\begin{tabular}{|c|c|c|c|c|}
\hline 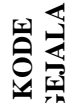 & GEJALA & $\sum$ & 空 & 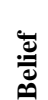 \\
\hline G001 & $\begin{array}{l}\text { Adanya bercak - bercak bulat melekuk ke } \\
\text { dalam pada buah, lekukan dapat bersatu } \\
\text { menjadi bercak besar tidak teratur }\end{array}$ & 0.9 & 0.1 & 0.9 \\
\hline G002 & $\begin{array}{l}\text { Bercak berwarna cokelat dengan titik hitam } \\
\text { yang terdiri dari aservulus jamur. }\end{array}$ & 0.9 & 0.1 & 0.9 \\
\hline G003 & $\begin{array}{l}\text { Adanya batang yang membusuk berwarna } \\
\text { kehitaman dan basah. }\end{array}$ & 0.9 & 0.1 & 0.9 \\
\hline G004 & $\begin{array}{l}\text { Adanya bercak memanjang pada bagian } \\
\text { tengah buah. }\end{array}$ & 0.8 & 0.2 & 0.8 \\
\hline G005 & Pada kulit buah terlihat bercak coklat & 0.8 & 0.2 & 0.8 \\
\hline G006 & $\begin{array}{l}\text { Hampir seluruh daging buah lembek dan } \\
\text { membusuk }\end{array}$ & 0.9 & 0.1 & 0.9 \\
\hline G007 & $\begin{array}{l}\text { Buah terong terlepas dari tangkai pada } \\
\text { bagian kelopak }\end{array}$ & 0.7 & 0.3 & 0.7 \\
\hline G008 & $\begin{array}{l}\text { Pada pangkal batang (leher akar) ada } \\
\text { miselium jamur berwarna putih seperti bulu } \\
\text { - bulu halus }\end{array}$ & 0.8 & 0.2 & 0.8 \\
\hline G009 & $\begin{array}{l}\text { Pada pangkal batang yang membusuk, kulit } \\
\text { terkelupas dan basah berwarna kecoklatan }\end{array}$ & 0.7 & 0.3 & 0.7 \\
\hline G010 & Tanaman menjadi layu, rebah dan mati. & 0.6 & 0.4 & 0.6 \\
\hline G011 & Daun tanaman tampak layu. & 0.7 & 0.3 & 0.7 \\
\hline G012 & Jaringan pembuluh kayu berwarna cokelat. & 0.8 & 0.2 & 0.8 \\
\hline G013 & Tampak bergaris - garis kemerahan & 0.6 & 0.4 & 0.6 \\
\hline G014 & $\begin{array}{l}\text { Tanaman menjadi kerdil, daunnya layu, dan } \\
\text { diikuti kematian tanaman dengan cepat }\end{array}$ & 0.7 & 0.3 & 0.7 \\
\hline
\end{tabular}

\begin{tabular}{|c|c|c|c|c|}
\hline 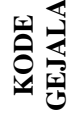 & GEJALA & $\sum$ & $\sum$ & 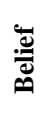 \\
\hline G015 & $\begin{array}{l}\text { Tulang daun tampak menguning, dimulai } \\
\text { dari daun tua }\end{array}$ & 0.8 & 0.2 & 0.8 \\
\hline G016 & $\begin{array}{l}\text { Bila batang sudah terserang, seluruh } \\
\text { tanaman akan layu. }\end{array}$ & 0.7 & 0.3 & 0.8 \\
\hline G017 & $\begin{array}{l}\text { Cendawan berada di dalam pembuluh kayu } \\
\text { dan menyebabkan jaringan tersebut } \\
\text { berwarna cokelat. }\end{array}$ & 0.8 & 0.2 & 0.8 \\
\hline G018 & Tanaman layu pada siang hari & 0.8 & 0.2 & 0.8 \\
\hline G019 & $\begin{array}{l}\text { Adanya bercak cokelat berbentu bulat pada } \\
\text { daun tua }\end{array}$ & 0.7 & 0.3 & 0.8 \\
\hline G020 & Daun Berwarna kuning dan rontok & 0.7 & 0.3 & 0.8 \\
\hline G021 & $\begin{array}{l}\text { Bercak daun pada musim hujan akan cepat } \\
\text { menyebar keseluruh daun tanaman }\end{array}$ & 0.6 & 0.4 & 0.6 \\
\hline G022 & $\begin{array}{l}\text { Pangkal batang bibit yang masih lunak } \\
\text { tampak busuk dan mongering }\end{array}$ & 0.8 & 0.2 & 0.8 \\
\hline G023 & Bibit yang terserang akan layu dan mati & 0.9 & 0.1 & 0.9 \\
\hline G024 & $\begin{array}{l}\text { Batang bibit muda kebasah }- \text { basahan, } \\
\text { mengkerut dan akhirnya akan mati }\end{array}$ & 0.8 & 0.2 & 0.8 \\
\hline G025 & $\begin{array}{l}\text { Warna cokelat di pangkal akar dan akar } \\
\text { membusuk }\end{array}$ & 0.9 & 0.1 & 0.9 \\
\hline
\end{tabular}

\subsection{Flowchart}

Pada Gambar 3 menjelaskan alur sistem memilih gejala penyakit sesuai dengan gejala penyakit yang dialami petani pada tanaman terongnya, kemudian sistem mengolah data menggunakan metode Dempster Shafer dan Certainty Factor untuk mencari nilai kepercyaan tertinggi untuk menentukan jenis penyakitnya, sehingga sistem menyimpulkan jenis penyakit dan akan memberikan solusi pengendaliannya.

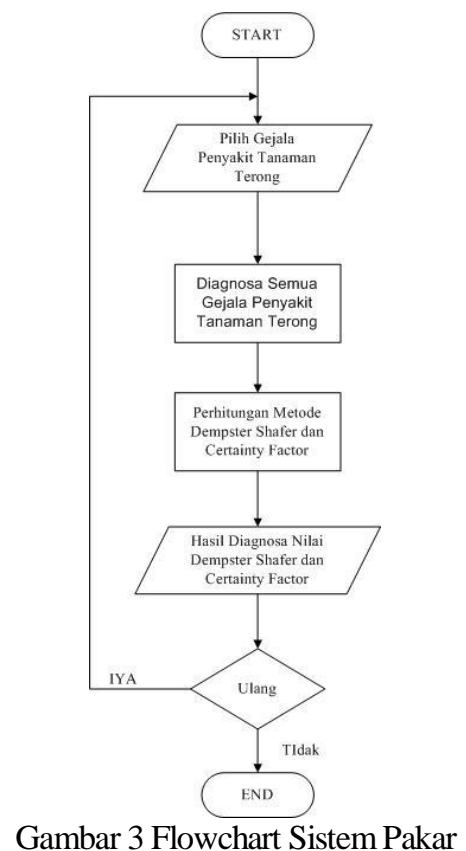

Pada Gambar 4 menjelaskan tentang alur perhitungan dari metode Dempster shafer. Langkah pertama memilih gejala terlebih dahulu kemudian menentukan jumlah densistas maksimum dari gejala terpilih, kemudian menghitung setiap gejala terpilih 
untuk mencari nilai densitas dari setiap gejala penyakitnya.

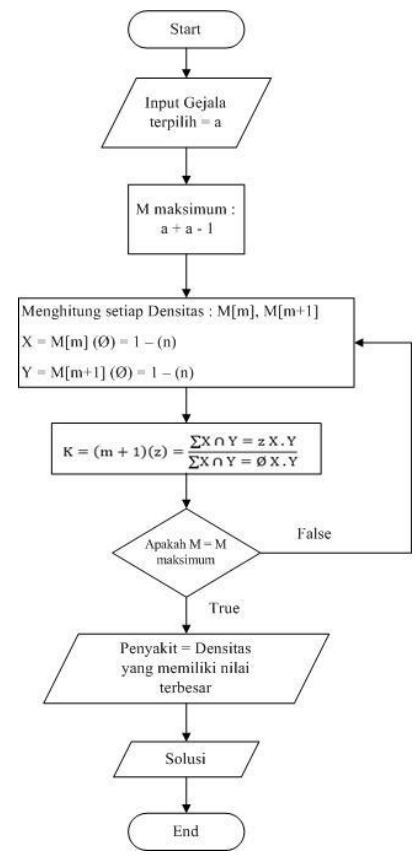

Gambar 4 Flowchart Metode Dempster Shafer

Jadi perhitungnya membandingkan satu persatu setiap gejala terpilih untuk mencari nilai densitas terbesar dan mencari nilai kombinasi dari setiap gejala yang dihitung. Dilakukan semua perhitungan terhadap gejala terpilih sampai $M$ atau Densitas maksimum terpenuhi atau semua gejala selesai dihitung. Untuk dapat menentukan jenis penyakit yang menyerang tanaman terong dicari nilai densistas yang terbesar dari perbandingan gejalanya maka akan muncul jenis penyakit dan akan ada solusi pengendaliannya.

Pada Gambar 5 menjelaskan tentang alur metode Certainty Factor. Sistem memilih gejala yang akan di diagnosis menggunakan metode Certainty Factor sesuai dengan gejala yang dialami pada penyakit tanaman terong. kemudian sistem menentukan jumlah gejala yang dipilih jika jumlah gejala berjumlah 1 , maka rumus yang digunakan adalah " $\mathrm{CF}=\mathrm{MB}-$ MD" dan jika jumlah gejala yang dipilih dengan penyakit sama berjumlah 2, maka rumus yang digunakan adalah "CF Combinasi $=\mathrm{CF} 1+\mathrm{CF} 2 \times[1$ - CF1]" dan jika jumlah gejala penyakit yang dipilih sama dengan penyakitnya berjumlah 3 , maka rumus yang digunakan adalah " $\mathrm{CF}$ Old $=\mathrm{CF}$ old $+\mathrm{CF} 3 \times$ (1 - CF old)..

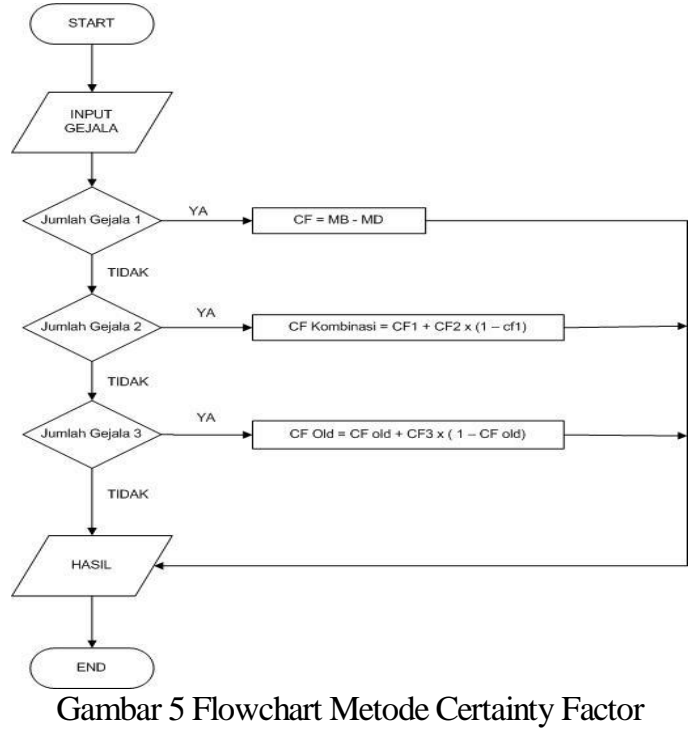

\section{HASIL DAN PEMBAHASAN}

4.1 Hasil

1. Tampilan Halaman Konsultasi

Pada Gambar 6 menu tampilan konsultasi digunakan untuk user memilih beberapa gejala penyakit dengan mengisi centang checkboxnya.

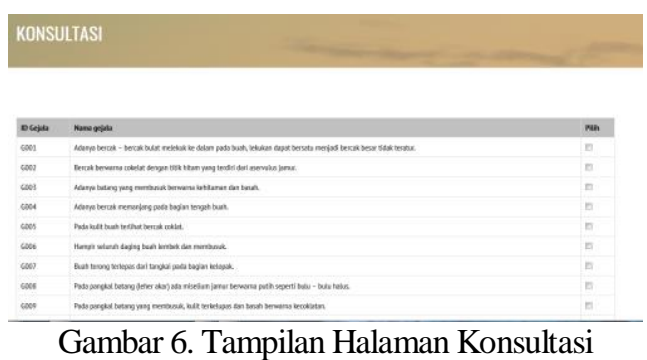

\section{Tampilam Halaman Hasil Diagnosis}

Pada Gambar 7 menu hasil diagnosis ini menampilkan hasil perhitungan dari kedua metode dan memberikan informasi penyakit dan solusinya.

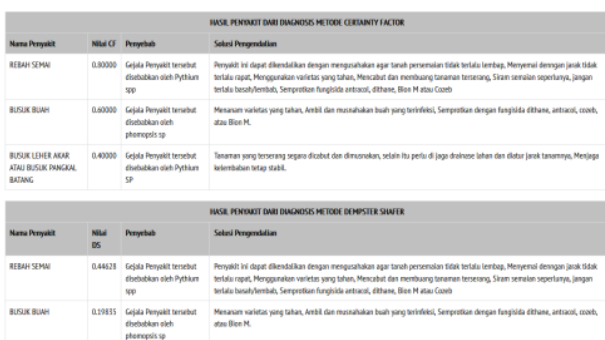

Gambar 7 Menu Hasil Diagnosis 


\subsection{Pengujian Fungsi Dan Kuisoner}

1. Pengujian Perbandingan Metode

A. Perbandingan Panjang Script

Pada perbandingan panjang script dari kedua metode ini yaitu dibandingan seberapa banyak baris untuk membuat metode Dempster Shafer dan Certainty Factor. Jumlah baris dalam pembuatan metode Certainty Factor adalah sebanyak 127 baris script untuk pembuatan metode Certainty Factor, sedangkan untuk jumlah baris dalam pembuatan metode Dempster shafer adalah sebanyak 205 baris Script untuk pembuatan metode Dempster shafer. Jadi untuk perbandingan panjang script lebih banyak script pada metode Dempster Shafer yaitu sebanyak 205 baris script

\section{B. Perbandingan Lama Proses kedua metode.}

Tabel 3 Perbandingan Lama Proses kedua Metode.

\begin{tabular}{|c|c|c|c|}
\hline NO & $\begin{array}{c}\text { Jumlah } \\
\text { Gejala Yang } \\
\text { dipilih }\end{array}$ & $\begin{array}{c}\text { Lama Proses } \\
\text { Metode } \\
\text { Dempster } \\
\text { Shafer }\end{array}$ & $\begin{array}{c}\text { Lama Proses } \\
\text { Metode } \\
\text { Certainty } \\
\text { Factor }\end{array}$ \\
\hline 1 & 1 Gejala & 0.001 Detik & 0.018 Detik \\
\hline 2 & 2 Gejala & 0.002 Detik & 0.002 Detik \\
\hline 3 & 3 Gejala & 0.004 Detik & 0.004 Detik \\
\hline 4 & 4 Gejala & 0.002 Detik & 0.006 Detik \\
\hline 5 & 5 Gejala & 0.021 Detik & 0.005 Detik \\
\hline 6 & 6 Gejala & 0.003 Detik & 0.007 Detik \\
\hline 7 & 7 Gejala & 0.003 Detik & 0.005 Detik \\
\hline 8 & 8 Gejala & 0.023 Detik & 0.009 Detik \\
\hline 9 & 9 Gejala & 0.004 Detik & 0.006 Detik \\
\hline 10 & 10Gejala & 0.008 Detik & 0.006 Detik \\
\hline
\end{tabular}

\section{Perbandingan Hasil Diagnosis Penyakit}

Tabel 4 Perbandingan hasil diagnosis penyakit

\begin{tabular}{|c|c|c|c|c|}
\hline NO & Gejala yang di Pilih & $\begin{array}{c}\text { Metode } \\
\text { Dempster } \\
\text { Shafer }\end{array}$ & $\begin{array}{l}\text { Metode } \\
\text { Certainty } \\
\text { Factor }\end{array}$ & $\begin{array}{l}\text { Hasil } \\
\text { Pakar }\end{array}$ \\
\hline 1 & $\begin{array}{l}\text { 1. Adanya batang yang membusuk berwarna kehitaman dan basah. } \\
\text { 2. Hampir seluruh daging buah lembek dan membusuk. } \\
\text { 3. Pada pangkal batang yang membusuk, kulit terkelupas dan basah } \\
\text { berwarna kecoklatan. } \\
\text { 4. Tanaman menjadi layu, rebah dan mati. } \\
\text { 5. Adanya bercak cokelat berbentu bulat pada daun tua. }\end{array}$ & $\begin{array}{c}\text { Penyakit } \\
\text { Antraknosa }\end{array}$ & $\begin{array}{c}\text { Penyakit } \\
\text { Antraknosa }\end{array}$ & $\begin{array}{c}\text { Penyakit } \\
\text { Busuk } \\
\text { Pangkal } \\
\text { Batang }\end{array}$ \\
\hline 2 & $\begin{array}{l}\text { 1. Adanya bercak memanjang pada bagian tengah buah. } \\
\text { 2. Hampir seluruh daging buah lembek dan membusuk. } \\
\text { 3. Pada pangkal batang (leher akar) ada miselium jamur berwarna putih } \\
\text { seperti bulu - bulu halus. } \\
\text { 4. Jaringan pembuluh kayu berwarna cokelat. } \\
\text { 5. Tampak bergaris - garis kemerahan. } \\
\text { 6. Tanaman layu pada siang hari. }\end{array}$ & $\begin{array}{l}\text { Penyakit } \\
\text { Busuk } \\
\text { Buah }\end{array}$ & $\begin{array}{l}\text { Penyakit } \\
\text { Busuk } \\
\text { Leher Akar } \\
\text { Atau } \\
\text { Busuk } \\
\text { Pangkal } \\
\text { Batang }\end{array}$ & $\begin{array}{l}\text { Penyakit } \\
\text { Busuk } \\
\text { Buah }\end{array}$ \\
\hline 3 & $\begin{array}{l}\text { 1. Adanya bercak memanjang pada bagian tengah buah. } \\
\text { 2. Pada kulit buah terlihat bercak coklat. } \\
\text { 3. Hampir seluruh daging buah lembek dan membusuk. } \\
\text { 4. Tampak bergaris - garis kemerahan. } \\
\text { 5. Tanaman menjadi kerdil, daunnya layu, dan diikuti kematian tanaman } \\
\text { dengan cepat }\end{array}$ & $\begin{array}{l}\text { Penyakit } \\
\text { Busuk } \\
\text { Buah }\end{array}$ & $\begin{array}{l}\text { Penyakit } \\
\text { Busuk } \\
\text { Buah }\end{array}$ & $\begin{array}{l}\text { Penyakit } \\
\text { Busuk } \\
\text { Buah }\end{array}$ \\
\hline 4 & $\begin{array}{l}\text { 1. Daun tanaman tampak layu. } \\
\text { 2. Jaringan pembuluh kayu berwarna cokelat. } \\
\text { 3. Bibit yang terserang akan layu dan mati } \\
\text { 4. Batang bibit muda kebasah - basahan, mengkerut dan akhirnya akan } \\
\text { mati } \\
\text { 5. Warna cokelat di pangkal akar dan akar membusuk. }\end{array}$ & $\begin{array}{l}\text { Penyakit } \\
\text { Rebah } \\
\text { Semai }\end{array}$ & $\begin{array}{l}\text { Penyakit } \\
\text { Rebah } \\
\text { Semai }\end{array}$ & $\begin{array}{l}\text { Penyakit } \\
\text { Rebah } \\
\text { Semai }\end{array}$ \\
\hline 5 & $\begin{array}{l}\text { 1. Jaringan pembuluh kayu berwarna cokelat. } \\
\text { 2. Tampak bergaris - garis kemerahan. } \\
\text { 3. Cendawan berada di dalam pembuluh kayu dan menyebabkan jaringan } \\
\text { tersebut berwarna cokelat. } \\
\text { 4. Daun Berwarna kuning dan rontok } \\
\text { 5. Pangkal batang bibit yang masih lunak tampak busuk dan mengering }\end{array}$ & $\begin{array}{l}\text { Penyakit } \\
\text { Layu } \\
\text { Bakteri }\end{array}$ & $\begin{array}{l}\text { Penyakit } \\
\text { Layu } \\
\text { Fusarium }\end{array}$ & $\begin{array}{l}\text { Penyakit } \\
\text { Layu } \\
\text { Bakteri }\end{array}$ \\
\hline 6 & $\begin{array}{l}\text { 1. Tanaman layu pada siang hari } \\
\text { 2. Adanya bercak cokelat berbentu bulat pada daun tua } \\
\text { 3. Bercak daun pada musim hujan akan cepat menyebar keseluruh daun } \\
\text { tanaman } \\
\text { 4. Bibit yang terserang akan layu dan mati } \\
\text { 5. Warna cokelat di pangkal akar dan akar membusuk }\end{array}$ & $\begin{array}{l}\text { Penyakit } \\
\text { Rebah } \\
\text { Semai }\end{array}$ & $\begin{array}{l}\text { Penyakit } \\
\text { Bercak } \\
\text { Daun }\end{array}$ & $\begin{array}{c}\text { Penyakit } \\
\text { Bercak } \\
\text { Daun }\end{array}$ \\
\hline 7 & $\begin{array}{l}\text { 1. Pada kulit buah terlihat bercak coklat. } \\
\text { 2. Hampir seluruh daging buah lembek dan membusuk. } \\
\text { 3. Buah terong terlepas dari tangkai pada bagian kelopak. }\end{array}$ & $\begin{array}{l}\text { Penyakit } \\
\text { Busuk } \\
\text { Buah }\end{array}$ & $\begin{array}{l}\text { Penyakit } \\
\text { Layu } \\
\text { Fusarium }\end{array}$ & $\begin{array}{l}\text { Busuk } \\
\text { Buah }\end{array}$ \\
\hline
\end{tabular}




\begin{tabular}{|c|c|c|c|c|}
\hline NO & Gejala yang di Pilih & $\begin{array}{l}\text { Metode } \\
\text { Dempster } \\
\text { Shafer }\end{array}$ & $\begin{array}{l}\text { Metode } \\
\text { Certainty } \\
\text { Factor }\end{array}$ & $\begin{array}{l}\text { Hasil } \\
\text { Pakar }\end{array}$ \\
\hline & $\begin{array}{l}\text { 4. Pada pangkal batang yang membusuk, kulit terkelupas dan basah } \\
\text { berwarna kecoklatan. } \\
\text { 5. Tanaman menjadi layu, rebah dan mati. } \\
\text { 6. Tampak bergaris - garis kemerahan. }\end{array}$ & & & \\
\hline 8 & $\begin{array}{l}\text { 1. Jaringan pembuluh kayu berwarna cokelat. } \\
\text { 2. Tampak bergaris - garis kemerahan. } \\
\text { 3. Tulang daun tampak menguning, dimulai dari daun tua } \\
\text { 4. Cendawan berada di dalam pembuluh kayu dan menyebabkan jaringan } \\
\text { tersebut berwarna cokelat. } \\
\text { 5. Tanaman layu pada siang hari }\end{array}$ & $\begin{array}{l}\text { Penyakit } \\
\text { Layu } \\
\text { Fusarium }\end{array}$ & $\begin{array}{l}\text { Penyakit } \\
\text { Layu } \\
\text { Fusarium }\end{array}$ & $\begin{array}{l}\text { Penyakit } \\
\text { Layu } \\
\text { Fusarium }\end{array}$ \\
\hline 9 & $\begin{array}{l}\text { 1. Adanya bercak memanjang pada bagian tengah buah. } \\
\text { 2. Pada pangkal batang yang membusuk, kulit terkelupas dan basah } \\
\text { berwarna kecoklatan. } \\
\text { 3. Tanaman layu pada siang hari } \\
\text { 4. Warna cokelat di pangkal akar dan akar membusuk }\end{array}$ & $\begin{array}{l}\text { Penyakit } \\
\text { Rebah } \\
\text { Semai }\end{array}$ & $\begin{array}{c}\text { Penyakit } \\
\text { Rebah } \\
\text { Semai }\end{array}$ & $\begin{array}{l}\text { Penyakit } \\
\text { Rebah } \\
\text { Semai }\end{array}$ \\
\hline 10 & $\begin{array}{l}\text { 1. Adanya bercak - bercak bulat melekuk ke dalam pada buah, lekukan } \\
\text { dapat bersatu menjadi bercak besar tidak teratur. } \\
\text { 2. Bercak berwarna cokelat dengan titik hitam yang terdiri dari aservulus } \\
\text { jamur. } \\
\text { 3. Pada kulit buah terlihat bercak coklat. } \\
\text { 4. Hampir seluruh daging buah lembek dan membusuk. } \\
\text { 5. Buah terong terlepas dari tangkai pada bagian kelopak. } \\
\text { 6. Tulang daun tampak menguning, dimulai dari daun tua } \\
\text { 7. Bila batang sudah terserang, seluruh tanaman akan layu }\end{array}$ & $\begin{array}{c}\text { Penyakit } \\
\text { Busuk } \\
\text { Buah }\end{array}$ & $\begin{array}{c}\text { Penyakit } \\
\text { Busuk } \\
\text { Buah }\end{array}$ & $\begin{array}{c}\text { Penyakit } \\
\text { Busuk } \\
\text { Buah }\end{array}$ \\
\hline
\end{tabular}

Pada Tabel 4 Perbandingan hasil diagnoisi penyakit dari metode dempster shafer, certainty factor dan Hasil dari pakar. Didapatkan hasil metode Dempster Shafer lebih baik dari Certainty Factor karena hasil presentase diagnosis penyakit yang sama dengan pakar yaitu lebih besar dibandingkan Certainty Factor dengan nilai presentase $80 \%$.

\section{Pengujian Fungsional Sistem}

Tabel 5 Pengujian Fungsional sistem

\begin{tabular}{|c|c|c|c|c|}
\hline \multirow[b]{2}{*}{ Akses } & \multirow[b]{2}{*}{ Fungsi } & \multicolumn{3}{|c|}{ Browser } \\
\hline & & 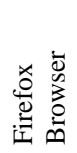 & 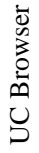 & 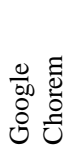 \\
\hline \multirow{11}{*}{ 总. } & Login Admin & $\checkmark$ & $\checkmark$ & $\checkmark$ \\
\hline & Tambah Penyakit & $\checkmark$ & $\checkmark$ & $\checkmark$ \\
\hline & Edit Penyakit & $\checkmark$ & $\checkmark$ & $\checkmark$ \\
\hline & Hapus Penyakit & $\checkmark$ & $\checkmark$ & $\checkmark$ \\
\hline & Tambah Gejala & $\checkmark$ & $\checkmark$ & $\checkmark$ \\
\hline & Edit Gejala & $\checkmark$ & $\checkmark$ & $\checkmark$ \\
\hline & Hapus Gejala & $\checkmark$ & $\checkmark$ & $\checkmark$ \\
\hline & Tambah Solusi & $\checkmark$ & $\checkmark$ & $\checkmark$ \\
\hline & Edit Solusi & $\checkmark$ & $\checkmark$ & $\checkmark$ \\
\hline & Hapus Solusi & $\checkmark$ & $\checkmark$ & $\checkmark$ \\
\hline & Logout & $\checkmark$ & $\checkmark$ & $\checkmark$ \\
\hline \multirow{3}{*}{ 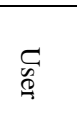 } & Checklist pada setiap gejala & $\checkmark$ & $\checkmark$ & $\checkmark$ \\
\hline & $\begin{array}{l}\text { Klik Proses Diagnosis pada } \\
\text { Button Proses }\end{array}$ & $\checkmark$ & $\checkmark$ & $\checkmark$ \\
\hline & Hasil Diagnosis & $\checkmark$ & $\checkmark$ & $\checkmark$ \\
\hline
\end{tabular}

Keterangan :

$\checkmark$ : Berhasil ; X : Tidak Berhasil

Pada pengujian tersebut didapat seluruh fungsi sistem dapat berjalan 100\% pada browser Mozila firefox 71.0b11 (32-bit), Google Chrome
7.0.185.1002 dan UC browser Version 69.0.3497.100 (32-bit).

\section{Pengujian User}

Tabel 6 Pengujian User

\begin{tabular}{|c|c|c|c|c|}
\hline \multirow{2}{*}{ NO } & \multirow{2}{*}{ PERTANYAAN } & \multicolumn{3}{|c|}{ JAWABAN } \\
\hline & & $\mathbf{S}$ & K S & T S \\
\hline 1 & $\begin{array}{l}\text { Apakah tampilan menu website sudah } \\
\text { menarik dan dalam segi tampilan dan } \\
\text { gambar.? }\end{array}$ & 20 & & \\
\hline 2 & $\begin{array}{l}\text { Apakah menu informasi tanaman terong } \\
\text { sudah memberikan beberapa informasi } \\
\text { yang jelas tentang website sistem pakar } \\
\text { tanaman diagnosis tanaman terong }\end{array}$ & 19 & 1 & \\
\hline 3 & $\begin{array}{l}\text { Apakah navigasi pemilihan gejala } \\
\text { berupa "checkbox" pada menu } \\
\text { konsultasi mudah digunakan? }\end{array}$ & 13 & 7 & \\
\hline 4 & $\begin{array}{l}\text { Apakah navigasi tombol proses untuk } \\
\text { menghasilkan kesimpulan penyakit bisa } \\
\text { anda pahami dan informasi yang diapat } \\
\text { jelas atau tidak.? }\end{array}$ & 18 & 2 & \\
\hline 5 & $\begin{array}{l}\text { Apakah perpaduan warna background } \\
\text { dan warna tulisan pada sistem terlihat } \\
\text { jelas pada pandangan mata anda } \\
\text { sehingga mudah dilihat? }\end{array}$ & 14 & 6 & \\
\hline 6 & $\begin{array}{l}\text { Apakah perpaduan warna background } \\
\text { dengan warna semua elemen halaman } \\
\text { (tombol,menu,garis 236epid an ikon) } \\
\text { pada sistem menurut anda sudh jelas } \\
\text { atau tidak.? }\end{array}$ & 16 & 3 & 1 \\
\hline 7 & $\begin{array}{l}\text { Apakah website sistem pakar ini bisa } \\
\text { membantu anda untuk mendiagnosis } \\
\text { penyakit pada tanaman terong. }\end{array}$ & 19 & 1 & \\
\hline 8 & $\begin{array}{l}\text { Apakah menu kontak kami dan kontak } \\
\text { pakar pada website sudah memberikan } \\
\text { informasi jelas tentang pembuat website } \\
\text { dan pakar yang membantu dalam } \\
\text { memberi datanya. }\end{array}$ & 18 & 2 & \\
\hline 9 & $\begin{array}{l}\text { Apakah alur informasi pada website } \\
\text { mudah dipahami.? }\end{array}$ & 17 & 3 & \\
\hline & Total & 154 & 25 & 1 \\
\hline
\end{tabular}


Keterangan :

S : Setuju

KS : Kurang Setuju

TS : Tidak Setuju

Jumlah Pertanyaan $=9$

Jumlah Responden $=20$

Faktor Pembagi $=9 \times 20=180$

a. Presentase responden memilih setuju $(154 / 180 * 100 \%)=85 \%$

b. Presentase responden memilih kurang setuju $(25 / 180 \times 100 \%)=14 \%$

c. Presentase responden memilih tidak setuju $(1 / 180 \times 100 \%)=1 \%$

\section{Pengujian Pakar}

Untuk memudahkan halaman pengujian pakar pada Tabel 7 Pengujian Pakar ada keterangan pengisian quisoner yaitu : S: Setuju,

KS : Kurang Setuju, dan TS : Tidak Setuju

\section{Tabel 7 Pengujian Pakar}

\begin{tabular}{|c|c|c|c|c|}
\hline \multirow{2}{*}{ NO } & \multirow{2}{*}{ PERTANYAAN } & \multicolumn{3}{|c|}{ JAWABAN } \\
\hline & & $\mathbf{S}$ & \multicolumn{2}{|c|}{ 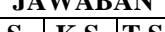 } \\
\hline 1 & $\begin{array}{l}\text { Apakah tampilan menu website sudah } \\
\text { menarik dan dalam segi tampilan dan } \\
\text { gambar.? }\end{array}$ & & 1 & \\
\hline 2 & $\begin{array}{l}\text { Apakah menu informasi tanaman terong } \\
\text { sudah memberikan beberapa informasi } \\
\text { yang jelas tentang website sistem pakar } \\
\text { tanaman diagnosis tanaman terong }\end{array}$ & 1 & & \\
\hline 3 & $\begin{array}{l}\text { Apakah navigasi pemilihan gejala berupa } \\
\text { "checkbox" pada menu konsultasi mudah } \\
\text { digunakan? }\end{array}$ & 1 & & \\
\hline 4 & $\begin{array}{l}\text { Apakah navigasi tombol proses untuk } \\
\text { menghasilkan kesimpulan penyakit bisa } \\
\text { anda pahami dan informasi yang diapat } \\
\text { jelas atau tidak.? }\end{array}$ & 1 & & \\
\hline 5 & $\begin{array}{l}\text { Apakah perpaduan warna background dan } \\
\text { warna tulisan pada sistem terlihat jelas } \\
\text { pada pandangan mata anda sehingga } \\
\text { mudah dilihat? }\end{array}$ & & 1 & \\
\hline 6 & $\begin{array}{l}\text { Apakah perpaduan warna background } \\
\text { dengan warna semua elemen halaman } \\
\text { (tombol,menu,garis tepi dan ikon) pada } \\
\text { sistem menurut anda sudh jelas atau tidak.? }\end{array}$ & & 1 & \\
\hline 7 & $\begin{array}{l}\text { Apakah website sistem pakar ini bisa } \\
\text { membantu anda untuk mendiagnosis } \\
\text { penyakit pada tanaman terong. }\end{array}$ & 1 & & \\
\hline 8 & $\begin{array}{l}\text { Apakah menu kontak kami dan kontak } \\
\text { pakar pada website sudah memberikan } \\
\text { informasi jelas tentang pembuat website } \\
\text { dan pakar yang membantu dalam memberi } \\
\text { datanya. }\end{array}$ & 1 & & \\
\hline 9 & $\begin{array}{l}\text { Apakah alur informasi pada website mudah } \\
\text { dipahami.? }\end{array}$ & 1 & & \\
\hline 10 & $\begin{array}{l}\text { Apakah CRUD dihalaman admin mudah } \\
\text { digunakan dan dipahami penggunaanya.? }\end{array}$ & 1 & & \\
\hline & Total & 7 & 3 & \\
\hline
\end{tabular}

Keterangan:

a. Presentase setuju $(7 / 10 * 100 \%)=70 \%$

b. Presentase kurang setuju $(/ 10 * 100 \%)=30 \%$

c. Presentase tidak setuju $(0 / 10 * 100 \%)=0 \%$

\section{Pengujian Metode Dempster Shafer Dan Certainty Factor}

Tabel 8 Pengujian hasil error.

\begin{tabular}{|c|c|c|c|c|}
\hline No & Kasus & $\begin{array}{c}\text { Perhitungan } \\
\text { Sistem }\end{array}$ & $\begin{array}{c}\text { Perhitungan } \\
\text { manual }\end{array}$ & $\begin{array}{c}\text { Perhitungan } \\
\text { \% Error }\end{array}$ \\
\hline 1 & 5 Gejala & 0,62314 & 0,62314 & $0 \%$ \\
\hline 2 & 5 Gjeala & 0,50719 & 0,50718 & $0,00197 \%$ \\
\hline 3 & 6 Gejala & 0.43882 & 0,404447 & $8,5 \%$ \\
\hline 4 & 8 Gejala & 0,54391 & 0,51259 & $6,11 \%$ \\
\hline \multicolumn{5}{|c|}{ Rata - Rata } \\
\hline
\end{tabular}

Pada percobaan pengujian metode dempster shafer dan certainty factor didaparkan hasil pengujian error dari 4 kasus yang menghasilkan nilai rata - rata error didapatkan presentase $3,65 \%$.

\section{KESIMPULAN DAN SARAN}

\subsection{Kesimpulan} yaitu:

Adapun kesimpulan yang dapat penulis paparkan

1. Dari perbandingan hasil diagnosis penyakit dari kedua metode dengan hasil diagnosis dari pakar, metode yang lebih baik adalah metode DempsterShafer dengan nilai presentase hasil diagnosis yang sama dengan pakar $80 \%$

2. Dari hasil pengujian yang dilakukan oleh pakar didapatkan $70 \%$ pakar memilih setuju. dan $30 \%$ pakar memilih kurang setuju.

3. Dari hasil pengujian yang dilakukan oleh 20 user dari petani dapatkan hasil $85 \%$ user memilih setuju, $14 \%$ user memilih kurang setuju, dan $1 \%$ user tidak setuju.

4. Dari hasil pengujian perhitungan manual dan perhitungan sistem didapatkan rata - rata error 3,65\% perbedaan, tetapi hasil diagnosis penyakitnya antara perhitungan manual dan sistem sama.

\subsection{Saran}

Untuk pengembangan aplikasi website yang lebih baik, ada beberapa saran yaitu :

1. Aplikasi untuk diagnosis penyakit tanaman terong ini terdiri dari 7 penyakit dan 25 gejala sehingga untuk kedepannya sistem pakar ini dapat ditambahkan lebih banyak lagi jenis penyakit pada tanaman terong.

2. Aplikasi yang dibangun ini berbasis web dan untuk pengembangan aplikasi sistem pakar selanjutnya dapat dirubah menjadi sistem pakar diagnosis penyakit tanaman terong berbasis android. 


\section{DAFTAR PUSTAKA}

[1] Handayani, M., Taufiq, T., \& Soegiarto, S. (2017). Sistem Pakar Diagnosa Penyakit Tanaman Semangka Menggunakan Metode Dempster Shafer Berbasis Web. PROGRESIF, 12(1).

[2] Orisa, M., Santoso, P. B., \& Setyawati, O. (2014). Sistem Pakar Diagnosis Penyakit Kambing Berbasis Web Menggunakan Metode Certainty Factor. Jurnal EECCIS, 8(2), 151-156.

[3] Kurniawan, H., \& Rahmad, I. F. (2012). Perancangan Sistem Pakar Untuk Mendeteksi Penyakit Pada Tanaman Cabe Dengan Metode Certainty Factor. CCIT Journal, 5(2), 186-206.

[4] Maulana, J. R., Fitriyadi, F., \& Fitriani, R. (2017). Sistem pakar diagnosis penyakit tanaman karet dengan metode DempsterShafer. JUTISI, 5(1).
[5] Normawardah, N. (2019). SISTEM PAKAR DIAGNOSIS PENYAKIT TANAMAN JAGUNG MENGGUNAKAN METODE CERTAINTY FACTOR BERBASIS WEB. Jurnal Mahasiswa Teknik Informatika, 3(1), 219-226.

[6] Kusrini, Fl Sigit Suyantoro (Ed). 2006. Sistem Pakar Teori Dan Aplikasi. Yogyakarta:Andi

[7] Mahmudi, A., Rokhman, M. M., \& Prasetio, A. E. (2016). RANCANG BANGUN SISTEM PAKAR UNTUK MENDIAGNOSIS TANAMAN CABAI MENGGUNAKAN METODE BAYES. Jurnal Ilmiah Rekayasa dan Manajemen Sistem Informasi, 2(2), 85-90.

[8] Soestasad Adi. A, Sri Muryanti, dan Hendro Sunarjono, 2003, Budi Daya Terung Lokal \& Terung Jepang, Jak 